\title{
Features of the digitalization impact on the functioning of agricultural enterprises
}

\author{
N.M. Yechin*, Yu.A. Kitayov, D.P. Kravchenko, Z.Ch. Pak, and N.I. Chovgan \\ Belgorod State Agrarian University named after V.Ya. Gorin, Belgorod region, Russia
}

\begin{abstract}
Digitalization of representatives of the agricultural sector of the Russian Federation is one of the defining directions in the modern conditions of their activities. A special role in the development of the agro-industrial complex digitalization is influenced by "Industry 4.0", which identifies the development trends of most enterprises over the past 10 years. The article examines the features of digitalization impact on the functioning of agricultural enterprises. The evolution of technological patterns in agriculture is analyzed and the role of digitalization in the formation and development of modern technological production of agricultural products is revealed. Technological factors of updating the production base of agricultural enterprises are determined. The influence of digitalization on each separate subsystem of agricultural enterprises is considered with the determination of the overall synergetic effect.
\end{abstract}

\section{Introduction}

Scientific and technological progress, based on evolutionary changes in technics, technology, organization and management of production processes, is an integral component of the modern economic development of any society. Technological renewal, both of the production process and its management, acts as the basis for the effective functioning of economic systems and a guarantor of increasing the competitiveness of the latter in a volatile market environment. The level of technology use has the opposite effect on the economic, technical, technological, social, environmental and other aspects of the activities of enterprises of all domestic economy sectors without exception.

The high speed of transformation processes that occur in the agricultural sector of the economy causes a rapid change in many aspects of the development of agricultural enterprises. Digitalization is spreading to an increasing number of processes and phenomena occurring in agricultural enterprises that require appropriate research and determines their relevance.

The problems of technological development influence on the activities of agricultural enterprises are revealed in the scientific works of well-known domestic agricultural economists, among which we highlight the works of A.I. Altukhov, O.I. Vanyushin, A.Yu. Izmailov, A.V. Kurdyumov, S.B. Ognivtsev, I.G. Ushachev, A.A. Fomin, T.A. Shafikov, and others. Paying tribute to the listed scientists and practitioners, we note that the

${ }^{*}$ Corresponding author: 1echinnm50@mail.ru 
versatility and discussion of certain aspects of agricultural production digitalization necessitates further research in this direction.

\section{Materials and Methods}

The purpose of the article is to identify the impact of modern digital technologies on the functioning of agricultural enterprises by in-depth analysis of the main trends of digitalization and trends in scientific and technological development of agricultural production.

The methodological basis of the research was the principles of the "Industry 4.0" concept reflecting new approaches in production based on the mass introduction of information technologies in industry, large-scale automation of business processes and the spread of artificial intelligence.

\section{Results}

The dialectical approach to the analysis of the impact of digitalization of the functioning and development of agricultural enterprises involves a retrospective study of the evolutionary prerequisites for changing equipment, technology, organization and management of production processes. The solution of the scientific tasks set requires an indepth analysis of scientific and technological progress in the agricultural sector to comprehend the ideas of predecessors and identify the features of the process of agricultural production digitalization.

The permanent relevance of the study of the digitalization processes of the functioning of agricultural enterprises is due to scientific and technological progress in the agricultural sector and changes in the social and economic environment of the functioning of commodity producers [1]. This problem is gaining particular relevance in the context of the galloping development of agricultural technologies not only in the field of production, but also in the field of management. Analysis of the evolution of technological patterns in agriculture has determined the digitalization impact on the formation and development of a modern technological method of agricultural production (Table 1).

Having studied the technological patterns in agriculture and the main economic achievements that have become possible thanks to the use of the latest agricultural technologies (Table. 1), it can be stated that each subsequent stage of agricultural production development was marked by a significant accumulation of discoveries not only in the agricultural sector, but also in the economy, technology and society as a whole. The permanent influence of digital technologies on the functioning of agricultural enterprises is closely related to the fifth technological paradigm. Computing, measuring, electronic and fiber-optic equipment, software, robotics, information, and communication technologies form a reliable foundation for digitalization of production and management processes in agriculture.

Table 1. Technological patterns in agriculture.

\begin{tabular}{|l|l|l|}
\hline $\begin{array}{l}\text { Technological } \\
\text { structure (period of } \\
\text { dominance) }\end{array}$ & Basis of technological paradigm & $\begin{array}{l}\text { Leading economic achievements } \\
\text { in the field of agricultural } \\
\text { production }\end{array}$ \\
\hline I - 1770-1830 & $\begin{array}{l}\text { Agricultural engineering, breeding } \\
\text { selection, production of manual } \\
\text { tillage tools }\end{array}$ & $\begin{array}{l}\text { Formation of a rational system of } \\
\text { agriculture, increasing the } \\
\text { biological efficiency of agriculture }\end{array}$ \\
\hline II - 1830-1890 & $\begin{array}{l}\text { Production of animal-drawn } \\
\text { cultivation tools, transportation of }\end{array}$ & $\begin{array}{l}\text { Specialization of agricultural } \\
\text { production, increase in the speed }\end{array}$ \\
\hline
\end{tabular}




\begin{tabular}{|c|c|c|}
\hline & $\begin{array}{l}\text { agricultural products } \\
\text { transport), agricultural engineering }\end{array}$ & $\begin{array}{l}\text { of delivery of agricultural } \\
\text { products, agricultural export- } \\
\text { import operations }\end{array}$ \\
\hline III - 1880-1940 & $\begin{array}{l}\text { Production of agricultural } \\
\text { equipment (tractors, combines, } \\
\text { agricultural machinery), extraction } \\
\text { of mineral fertilizers, electrification } \\
\text { of agricultural production }\end{array}$ & $\begin{array}{l}\text { Significant increase in the yield of } \\
\text { agricultural crops, increase in the } \\
\text { agriculture marketability, release } \\
\text { of labor for other economy sectors }\end{array}$ \\
\hline IV - 1930-1980 & $\begin{array}{l}\text { Breeding and genetics of } \\
\text { agricultural crops, electric motors, } \\
\text { organic chemistry, synthetic } \\
\text { materials, feed industry }\end{array}$ & $\begin{array}{l}\text { Concentration, specialization, } \\
\text { mechanization and automation of } \\
\text { agricultural production, } \\
\text { livestock complexes, increase of } \\
\text { the shelf life of products, } \\
\text { standardization of production }\end{array}$ \\
\hline V - 1970-2030 & $\begin{array}{l}\text { Biotechnologies, computing, } \\
\text { measuring, electronic, fiber-optic } \\
\text { technology, software, robotics, } \\
\text { information and communication } \\
\text { technologies }\end{array}$ & $\begin{array}{l}\text { Production flexibility, } \\
\text { automated control systems, } \\
\text { increased production efficiency } \\
\text { (differentiated processing of fields } \\
\text { and accurate sowing of } \\
\text { agricultural crops, intelligent } \\
\text { application of mineral fertilizers, } \\
\text { etc.), improving the quality of life }\end{array}$ \\
\hline VI - 2020-2080 & $\begin{array}{l}\text { Plant and animal biotechnologies, } \\
\text { nanotechnology, robotics, artificial } \\
\text { intelligence, nano bionics, } \\
\text { optoelectronics }\end{array}$ & $\begin{array}{l}\text { Robotization of agricultural } \\
\text { production, reduction of } \\
\text { employment in the agricultural } \\
\text { sector, 3D production, } \\
\text { deurbanization, manufacturing of } \\
\text { products with new properties, } \\
\text { innovative technologies in } \\
\text { environmental management }\end{array}$ \\
\hline
\end{tabular}

According to the theory of cyclical socio-economic development of G. Condratiev [6] and technological paradigms (works of N. Tugan-Baranovsky [12], S. Glazyev [4]), computer technologies are not even present, but yesterday's technologies. Since the mid-70s of the XX century, the vector of technological development has been closely linked with information and communication technologies, microelectronics, the Internet, that is, technologies that are inherent in the process of digitalization, which is why digitalization acts as the locomotive of the transition to the next sixth technological paradigm.

Knowledge and information as the main factor of production, characteristic technologies of the VI technological paradigm, have opened up powerful opportunities for qualitatively new economic growth with the help of the following digital tools: commercial sites in the Internet (Internet commerce), development of horizontal management systems (information and communication technologies), possibility of multiple use of the resources available to the enterprise (within the cloud infrastructure of the enterprise), digital ecosystem and development of regional clusters of the digital economy, etc., which together will allow to find new points of economic growth and the emergence of "digital valleys" on this basis.

\section{Discussion}

The transition to higher technological stages in the agricultural sector of the economy requires updating the technical and technological base, means of production and management mechanisms of agricultural enterprises. The process of developing a strategy 
for technological renewal of agricultural production is based on the potential of technological development of commodity producers. In this case, the technological factors that should be given special attention during the technological renewal of agricultural enterprises include the following:

- degree of intensity of technological development of the agricultural sector (opportunities, frequency, payback and speed of innovation), characteristics of the agricultural market (market capacity, demand for products and export opportunities), age of the agricultural enterprise (determines the motivation for technological renewal, the introduction of digital innovations, the dynamism of innovation);

- specialization and size of the agricultural enterprise (the ability to make technological changes in production processes and the intensity of use of updated equipment);

- financial situation of the enterprise (determines the possibility of investing in the renewal of the technical and technological base of agricultural production);

- technological capabilities of an agricultural enterprise (existing potential for innovation, staff training to use innovations, improvement of existing technologies);

- enterprise development strategy (defines the vector of important management decisions and direct tools for introducing innovations);

- technological culture of an agricultural producer (outlines the susceptibility to technological renewal and the introduction of innovative developments into practical activities, both of an individual employee of the enterprise and of senior management).

In the conditions of agricultural production intellectualization, the latest digital technologies become the basis (foundation) that determines the technological level of agricultural production, changes the forms of organization and management of an agricultural enterprise, ensures a high level of manufacturer competitiveness, and allows to function effectively, considering the processes of world economic globalization.

The study of the digitalization impact on the functioning of agricultural enterprises involves, in our opinion, a detailed analysis of the main trends of digitalization in agriculture and trends in scientific and technological development of agricultural production, which will allow to identify individual digital components of the impact on the activities of commodity producers in the conditions of accelerated development and use of modern technologies. Table 2 presents the main trends of digitalization of agricultural enterprises and trends in scientific and technical development of agricultural production.

Table 2. Major trends of digitalization in agricultural enterprises and trends in scientific and technical development of agricultural production [10].

\begin{tabular}{|l|l|l|l|}
\hline $\begin{array}{l}\text { Technological trends of digitalization in } \\
\text { agricultural enterprises }\end{array}$ & $\begin{array}{l}\text { Characteristics of trends in scientific and } \\
\text { technical development of } \\
\text { production }\end{array}$ \\
\hline $\begin{array}{l}\text { Mass introduction of intelligent sensitive } \\
\text { elements and sensors in equipment and in } \\
\text { production }\end{array}$ & $\begin{array}{l}\text { Development of intelligent technologies in } \\
\text { agriculture. Improvement of production } \\
\text { processes }\end{array}$ \\
\hline Transition to cloud technologies & $\begin{array}{l}\text { Storage and processing of a large volume of } \\
\text { information. Carrying out calculations } \\
\text { (precision farming, crop rotations, application } \\
\text { of mineral fertilizers, etc.) with the help of own } \\
\text { capacities }\end{array}$ \\
\hline $\begin{array}{l}\text { End-to-end automation and integration of } \\
\text { production and management processes }\end{array}$ & $\begin{array}{l}\text { Development of the main, auxiliary and } \\
\text { managerial business processes of agro- } \\
\text { formations }\end{array}$ \\
\hline $\begin{array}{l}\text { Transition to mandatory digitization of } \\
\text { technical documentation }\end{array}$ & $\begin{array}{l}\text { Fast processing of information on technical } \\
\text { acumentation. Automatic reading } \\
\text { of }\end{array}$ \\
\hline
\end{tabular}




\begin{tabular}{|l|l|}
\hline & information using artificial intelligence \\
\hline $\begin{array}{l}\text { Digital design and modeling of technological } \\
\text { processes }\end{array}$ & $\begin{array}{l}\text { Precise design and modeling of technological } \\
\text { processes }\end{array}$ \\
\hline $\begin{array}{l}\text { Development of agricultural analytics } \\
\text { technologies }\end{array}$ & $\begin{array}{l}\text { Automation of agricultural analytics } \\
\text { technologies Increasing the speed of } \\
\text { information processing and providing it to } \\
\text { managers and other interested users }\end{array}$ \\
\hline Almost $100 \%$ disposal and recycling & $\begin{array}{l}\text { Improving the quality of life of the rural } \\
\text { population and improving the environmental } \\
\text { situation }\end{array}$ \\
\hline Internet technologies & $\begin{array}{l}\text { Monitoring the condition of soil and crops. } \\
\text { Quick response of the "seller" to the requests of } \\
\text { the "buyer". Choosing a "buyer" directly on the } \\
\text { seller's website, without providing intermediary } \\
\text { services and increasing the cost of finished } \\
\text { products }\end{array}$ \\
\hline
\end{tabular}

Analyzing the data in Table 2, we note that the digitalization of technological, economic, and managerial processes at each individual agricultural enterprise gradually affects the overall development of digital assets of agriculture in the Russian Federation. The existing digital assets of agricultural enterprises will allow to instantly respond to new challenges of the agricultural market and constantly develop both existing technologies and introduce innovative ones, which significantly strengthens the positions of domestic producers in open competition in the market of agro-industrial products.

Domestic agriculture is gradually turning from a traditional into a high-tech industry able to create new markets for innovative solutions and developments that did not exist before to solve many practical problems. The existing ones are being replaced by "smart" agricultural technologies based on machine learning, digital platforms, 3-D printing, robotics, blockchain, biosensors and Big Data. In the XXI century, intelligent digital solutions should help agricultural enterprises to cope with the problems of increasing the productivity and efficiency of the industry on the way to sustainable development.

Agricultural business entities that use digital technologies on a regular basis will be able to take advantage of convergence opportunities, in which data on products (processes) are available at all stages of its life cycle - from sowing crops to harvesting. Management digitalization allows the management of an agricultural enterprise to make decisions in conditions of full awareness of production processes within the organization and transformation for "rapid implementation" in terms of flexibility, quality, safety and operational efficiency. Agricultural enterprises which aim to become "digital" should focus on automation of production and management processes to make them more efficient, with a high involvement of employees in management decision-making.

Modern agricultural enterprise is characterized as a complex production and economic system that includes a significant number of subsystems, among which it is necessary to single out the most significant (from the point of view of ensuring the efficiency of functioning):

- technical;

- technological;

- economic;

- managerial;

- social;

- labor;

- environmental, etc. 
To one degree or another, each of the above subsystems is affected by the digitalization of agricultural production, and in a separate subsystem, agricultural enterprises have a common synergetic effect.

In addition, the synergetic effect of the digitalization impact on all subsystems of agricultural enterprises, without exception, is manifested in the possibilities of new points of economic growth and improved social and economic effect, including by reducing the costs of agricultural production. We emphasize that the relevance and inevitability of digitalization processes in the general economic scale of the Russian Federation are reflected in the approved Decree of the Government of the Russian Federation dated March 2, 2019 No. 234 "On the management system for the implementation of the national program "Digital Economy of the Russian Federation" (with amendments and additions, which reinforces the need to consider the trends, technologies and digital drivers described above in the practical activities of business entities) [13].

Nevertheless, practice shows that domestic agricultural enterprises need to realize the fatality of technological lag and the objectivity of the digitalization processes of agricultural production. At the same time, the above highlights the irreversibility of mobilizing the capabilities of agricultural enterprises to digitalize production and management processes for building a new model of dynamic economic development of agricultural formations for gradual integration into the technological trajectory of agrarian evolution.

The practical implementation of the planned tasks of digitalization of production and management processes requires the accumulation of efforts of agricultural enterprises in the context of an impartial and objective assessment of the real technological state of the producer in the context of the evolution of technical and economic structures to develop and implement effective economic and motivational incentives to ensure an accelerated transition to new digital technologies in production and management, which are inherent in the 5 th and 6 th technological paradigms.

\section{Conclusion}

The conducted research suggests that digital technological changes have a significant impact on the functioning and economic development of agricultural enterprises. The introduction of modern digital technologies into the practical activities of agricultural producers is the main driving force of progress in the agricultural sector. The new model of economic growth of agricultural enterprises, based on the information and digital type of development, provides for a change in the general paradigm of production process management. The priorities of the digital component of development are intellectualization of production and management activities, environmental friendliness, use of modern technologies, digital assistants, updating the technical and technological base, etc.

Thus, modern digitalization processes determine the competition of national economies for a worthy place in the global ranking of development and well-being of the population within countries. The objectivity of the described processes requires Russian society to form a model of dynamic development of the main sectors of the economy (especially agriculture, as its main driver) on an innovative basis and to mobilize all the capabilities of the state to adapt domestic enterprises to modern technological development trajectories.

\section{References}

1. A.A. Aitpaeva, Bulletin of the Astrakhan State Technical University. Series: Economics 3, 56-63 (2019) 
2. I.P. Boyko, M.A. Evnevich, A.V. Kolyshkin, Russian entrepreneurship 7, 1127-1136 (2017)

3. V.M. Volodin, N.A. Nadykina, News of higher educational institutions. Volga region. Economic sciences 2(8), 3-12 (2018)

4. S.Yu. Glazyev, Long waves: scientific and technological progress and socio-economic development, 358 (Novosibirsk, 1991)

5. P.A. Ivashev, I.V. Andronova, Alley of Science 6(33), 350-354 (2019)

6. N.D. Kondratiev, Large cycles of conjuncture and the theory of foresight. Selected works, 767 (Moscow, Ekonomika, 2002)

7. L.M. Kornilova, E.A. Ivanov, P.A. Ivanov, Innovative development of the economy 5(47), 52-58 (2018)

8. V.V. Luppov, Economics, labor, management in agriculture 10(43), 103-112 (2018)

9. S.B. Ognivtsev, International agricultural journal 2(362), 16-22 (2018)

10. S.V. Ponomareva, A.A. Khachaturian, A.S. Melnikova, Bulletin of SPbSPU. Economic sciences 11(4), 60-69 (2018)

11. N.M. Trendov, S. Varas, M. Tseng, Digital technologies in the service of agriculture and rural areas: a reference document Rome, 11-12 (FAO, United Nations, 2019)

12. M.I. Tugan-Baranovsky, Periodic industrial crises, 479 (Moscow, Directmedia Publishing, 2008)

13. Decree of the Government of the Russian Federation dated March 2, 2019 N 234 "On the management system for the implementation of the national program "Digital Economy of the Russian Federation" (with amendments and additions) https://base .garant.ru 